\title{
SEM Approach to Teen Influence in Family Decision Making
}

\author{
Anupriya Kaur \\ Jaypee University of Information Technology \\ E-Mail: kauranupriya@gmail.com \\ Yajulu Medury \\ Jaypee Education System \\ E-Mail: yaj.medury@jalindia.co.in
}

\begin{abstract}
The primary purpose of this paper is to provide an empirical design on teen influence and its predictors in the context of family decision making. Structure equation modeling (SEM) is employed to test the proposed conceptual model on teen influence and its predictors. The SEM approach also provides for the construct validity of the key measures. Results indicate that teenage children in urban Indian households significantly influence purchase-related decisions in the family. The findings from the empirical data suggest that peers, shopping and the Internet are significant predictors of teen influence in family purchases, although the media's role is marginalized (as a predictor) to the influence that teenagers have in family decision making. This study is significant, as great scholastic interest is placed on such contemporary research, which aims to discern the role of a variety of factors that impact teen influence in the family. This study also addresses the problem of construct validity of key measures, which has been somewhat overlooked in the past research.
\end{abstract}

Keywords: Indian Teenagers, Family Decision Making, Teen Influence, Consumer Socialization, SEM, Internet, Peers, Media and Shopping

\section{INTRODUCTION}

Wordsworth's immortal line "the child is the father of man" assumes new meaning in today's consumption-driven society, where the younger family members seem to influence, if not dominate, their elders. Children's influence in family decision making (FDM) is increasingly recognized and acknowledged by marketers, 
academicians and researchers alike to such an extent that, over the years, marketers especially those dealing with children - added another P to the list of the traditional 4 P's: "pester power", the ability of children to influence parents into buying decisions (Sethi, 2011). In the last two decades, a lot of headway has been made on exploring and understanding the factors surrounding the child's role in family purchase decisions. However, the existing body of research suffers from some limitations, which lay the grounds for the present research work. Primarily, much of the past research is dated and is less inclusive i.e. concentrated on Western nations. For example, virtually no such research has included Indian families and children. Additionally, past theoretical frameworks in this area, such as consumer socialization, need to be updated amidst a contemporary lifestyle and changes in society at large. But, the most basic problem plaguing this area is the weak construct validity of a key measure - child influence. Without doubt, the onus lies on contemporary research to address this problem. This research takes a step toward resolving the problem. The objectives of this paper are threefold: (1) to provide a conceptual framework on teen influence and its association with traditional and contemporary socialization agents; (2) to provide the design, measurement and validation of the key constructs; and (3) to test empirically the conceptual model via SEM analysis. Teenage children were specifically included, because, first, they are expected to have gained cognitive

abilities and some competence as consumers (Ekstrom, 1995). Further, due to the spending power controlled by the teenage demographic, this group is usually a trendsetter in terms of consumption patterns (Martin and Bush, 2000). In the sections that follow, first, the background for the study and research settings are described. This is followed by a discussion of teen influence and its association with socialization agents. Next, the empirical research design is presented. We conclude with a discussion of the findings and the implications of the study's results.

\section{BACKGROUND FOR THE STUDY AND RESEARCH SETTINGS}

According to the American Marketing Association, the youthfulness of many other countries - especially in Asia - far outstrips that of the US, where only $21 \%$ of the total population is aged 14 or younger, in contrast to India where $35 \%$ of the population is 14 or under (Stock and Tupot, 2006). With about 115.3 million teenagers, India has the largest teenage population in the world. In a decade, they will represent the largest percentage of the population in India (NRIFinanceGuide.com, 2008). Children are also the main focus of Indian families, and the aspirations of the children in terms of education and career choices are quite high today. The average 
family size in India has been on a decline, currently almost 4.3 people per family as compared to earlier years, when it was more than 5 . With the reduction in their average size and the increase in their incomes, Indian families have more money to spend. Since children are the main focus, parents try their best to fulfill their children's aspirations. Consequently, the children get more attention and have greater participation in the decision making process. Experts peg the market for products and services in which children play the role of an influencer at an astounding $\$ 100$ billion (Rs 450,000 crore) (Sethi, 2011). Evidently, children's consumer behavior and their influence in family purchase and consumption decisions in India merits rigorous research attention.

Academic research on Indian families and children, however, is conspicuously absent. The only exceptions are Singh and Kaur (2004) on purchase subdecisions; Hundal (2001) on rural buying behavior; and Kapoor (2001) on family members' influence across decision making stages. According to Webster (1994), India offers an interesting and diverse culture vastly different from the West in various social variables, thus meriting further research. Ruth and Commuri (1998) made a similar observation: "India is an apt environment for contemporary research because of the rapid socio-economic changes that have taken place in the last ten years". Indian markets hold much promise and are evolving rapidly. India ranks third in terms of commercial attractiveness in a Global Retail Development Index of thirty emerging countries (Kearney, 2010), and its retail market is expected to reach \$US81.46bn by 2020 at a compounded annual growth rate of more than 25 percent (Technopak Advisors, 2010). Indian consumers, too, across different strata and market segments, exhibit a behavior change in spending and consumption. As the family consumption patterns change, the family decision making is likewise going through a metamorphosis. Amongst several economic and social influences fuelling this metamorphosis, a visible and dominant factor is the increasing influence of children in family decision making. Changes in societal norms and traditions, a rise in connectivity, media invasion etc. directly impact children, thereby making them more knowledgeable and shopping savvy. Undeniably, academic research is required to understand better the consumer behavior of this large and important segment and to discern accurately the effects of contemporary changes on Indian children and families. 


\section{TEEN INFLUENCE AND ITS ASSOCIATION WITH SOCIALIZATION AGENTS}

Influence usually indicates that an individual's wishes are acted upon by someone else. Loudon and Bitta (1988) defined influence as "the effect or a change in a person's attitude or behavior as a result of communication with others". This is similar to Wilke's (1986) definition “that a consumer's decision process has somehow been affected by outside forces". Ekstrom (1995) applied the following definition in the context of the parent-child dyad: "a change in a person's dispositions as a result of interaction between parents and children". Ekstrom further stated that "different influence processes are believed to occur when parents and children interact and result in either influence or no influence". No influence implies that the influence process has resulted in a person not being influenced. It could be defined as no change in a person's dispositions as a result of interaction between parents and children. Wimalsari (2004) used the terms influence and persuasion in their study. Wimalsari contends that influence occurs any time a source (children) attempts to change a receiver's (parents) thoughts, feelings or behavior. Inducing a change in behavior is called compliance, and inducing a change in attitude is called persuasion. Persuasion is a special case of influence, whereby the source deliberately uses communication to try to change a target's attitude. It is evident, therefore, that influence has been looked at as a construct consisting of different dimensions, such as, for example, decision dominance (Belch et al., 1985); exercise of social power (Kim et al., 1990) and reference (Childers and Rao, 1992). In spite of the fact that 'child influence' in FDM has been a key construct across a number of studies (some of which are mentioned above), it remains an ill designed construct. The chief problem with the past empirical studies referred to above is that they measured the child's influence contextual to certain products or services, rather than in a generic manner. Although these studies provide a broad spectrum for understanding children's influence in family decision making, use of a particular product or service as a contextual reference in the empirical design of the measure - child influence - has its own limitations. Such variables as child and/or parental interest in the product, socio-economic conditions of the family, pocket allowance of children, etc., may indirectly affect and may distort results, unless these factors are controlled in the research model and/or statistical analysis.

As highlighted in the introduction, most studies have failed to define "influence" conceptually. A pertinent remark to this effect is by Ekstrom (1995): "Future research needs to further consider the many different meanings influence may involve; and 
explicitly define what is meant by influence. It will increase construct validity and hopefully eliminate the potential risk that the researcher and the respondents assign different meanings to the construct".

The authors in an earlier endeavor (Kaur and Medury, 2011a) made initial progress in this direction. In their earlier research, the authors undertook to examine the impact of familial characteristics on the influence of a teenage child, and the generic measure for child influence was first conceptualized. Using a step by step approach, the researchers initially conducted a semi-structured interview with eight families with teenage children with the aim to conceptualize correctly the construct of each child's influence in family decision making. Interviews were conducted with the parent-child dyad, and eventually an amalgamation of parent's and children's views resulted in the formulation of an initial multi-item scale, which encompassed four aspects of the child's influence on family decision-making: (1) parent's act of seeking information about products from the child; (2) co-shopping; (3) consideration of the child's request in case of conflict; and (4) participation of the child in general decision-making factors. The research instrument was designed, and a pilot study was conducted with 44 parent-child dyads randomly selected from the city of Delhi, India. Reliability analysis and exploratory factor analysis on the pilot and subsequently on the final data laid the way for the development of a 13-item purified scale, which was eventually used in the final study (see appendix 1). In this paper, the authors wish to extend this research further. The measure, which we call "teen influence", is further subjected to confirmatory factor analysis to achieve its complete validation. Furthermore, it serves as the criterion variable in the SEM model proposed in this paper in a later section.

\section{Major Influences on Consumer Socialization}

The consumer socialization of children, i.e. how children develop consumer skills, was a significant area of study that emerged from family consumption behavior around the 1980's. Marketing literature describes socialization as the process of learning consumer-related skills, knowledge and attitudes. Bush and Simons (1981) describe socialization as "the ways in which individuals learn skills, knowledge, values, motives and roles appropriate to their position in a group or a society". Extant literature has over the years clearly established the role of mass media, namely television, parents and peers, as prime influences on socialization (Roedder, 1999; Chavda et al., 2005). However, today, our societies, in the West and the East, are witnessing several changes, such as imparting a liberal upbringing to our children 
coupled with high media invasion and other hi-tech digitalized communication platforms. A variety of influences and experiences shape the consumer habits of the young consumer all over the world. For instance, children today spend more time in commercial settings than ever, such as shopping in stores, and are surrounded by commercial messages in a variety of forms (Wechsler, 1997). Yet, little is known about the effects of these activities on their consumer knowledge and skills. In addition, teenagers spend more time online than adults and surpass all other age groups in their use of chat, instant messaging and other new forms of electronic communication (Montgomery, 2000). As has been pointed by Lee et al. (2003), the increasing use of the Internet as a communication tool makes it a potentially strong agent of socialization. Therefore, it is highly imperative to link the present-day lifestyle and societal changes with the socialization process to further the theoretical concepts.

In our earlier research, a conceptual and empirical framework was provided that established shopping and the Internet as contemporary socialization agents (Kaur and Medury, 2010, 2011b). Based on the review of past literature and personal interaction with teenage children, constructs for measuring the influence of socialization agents (media, peers, shopping and the Internet) on teenage children were conceptualized on three major aspects: (1) the propensity to like and engage with the medium; (2) the ability to perceive information about products for self use, family use and adult use from the medium; and (3) the ability to disseminate product information learnt from the medium. Based on these aspects, a pool of items was formulated to measure these constructs. A four point Likert scale was considered to measure the scale items (see appendix 2). In this research, these measures are subjected to confirmatory factor analysis to provide for their construct validity, and they act as predictor variables in the SEM model.

This study applied the consumer socialization perspective to explore the traditional and contemporary socialization influences on teenagers and the subsequent outcome on teen influence in family decision making. In our research framework, we propose that the role of these socialization agents is not restricted to developing consumer competence and skills in teenagers but transcends to impact the level of influence that the teenager wields in the family purchase decisions. Media influence, peer influence, shopping influence and Internet influence act as predictors to teen influence in the family purchases (see figure 1). This is a first, as no previous study has comprehensively examined the role of these socialization agents on teen influence. It makes the study significant, as great scholastic interest is placed on such 
contemporary research, which aims to discern the role of a variety of factors that impact teen influence in the family. In the sections that follow, the research methodology and the model results are presented and the conclusions are discussed.

\section{RESEARCH METHODOLOGY}

\section{Data Sample}

A structured two part questionnaire, one for teenager's use and the other for parent's use, was used in data collection. Pre-test statements designed on a Likert scale to measure the influence of socialization agents were a part of each teenager's questionnaire and statements assessing their influence on FDM were a part of each parent's questionnaire. The questionnaire also included descriptive measures, including age, gender, monthly pocket allowances, household income, parents' occupation, etc. Based on convenience sampling, the instrument was administered to students in the ninth to twelfth grades at several schools located in Delhi, the capital of India. The first author conducted the administration of the child's part of the questionnaire in the school premises. The second part of the questionnaire to be filled by any one parent was sent home with the child with the request to bring it back in three days. A usable sample of 346 was obtained therefrom, which consisted of 178 female and 168 male adolescents. The children's ages ranged from 13 to 17 years, with the mean age being 14.87 years. The mean age of the parents was 42.64 years. The distribution of the household income per annum was as follows: 30.6 per cent in the income category of up to five lacs; 51.4 per cent between five lacs and 10 lacs; and 17.9 per cent were in the income category of more than 10 lacs per annum. None of the children had a working status as is the trend in school-going children in India. However, they received a regular pocket allowance, with 62.4 percent receiving an amount less than Rupees 1000; 35.3 per cent between Rupees 1000 and Rupees 2000; and 2.3 per cent receiving an amount of more than 2000 per month. All of the teenagers had Internet access at home and/or at school.

\section{SEM Approach}

Structural equation modeling (SEM) has been described as a combination of exploratory factor analysis and multiple regression (Ullman, 2001). SEM is an attempt to model causal relations between variables by including all variables that are known to have some involvement in the process of interest. Among SEM's strengths is its ability to construct latent variables, which are not measured directly, but are estimated 
in the model from several measured variables, each of which is predicted to "tap into" the latent variables. This allows the modeler to capture explicitly the unreliability of measurement in the model, which in theory allows the structural relations between latent variables to be accurately estimated. According to Schreiber et al. (2006), "SEM, in comparison with CFA, extends the possibility of relationships among the latent variables and encompasses two components: (a) a measurement model (essentially the CFA) and (b) a structural model. In addition to the new terms, measurement and structural, two other terms are associated with SEM: exogenous, similar to independent variables, and endogenous, similar to dependent or outcome variables. Exogenous and endogenous variables can be observed or unobserved, depending on the model being tested. Within the context of structural modeling, exogenous variables represent those constructs that exert an influence on other constructs under study and are not influenced by other factors in the quantitative model. Those constructs identified as endogenous are affected by exogenous and other endogenous variables in the model (p. 325)." In light of this discussion, the use of SEM is best suited to measure and model the major influences on consumer socialization and the impact of teen influence on FDM.

\section{MODEL DEVELOPMENT AND HYPOTHESIS}

This research examined the direct associations of media influence, peer influence, shopping influence, and Internet influence with teen influence in FDM. The conceptual model that guided this research is shown in figure 1. The observed variables are shown in rectangles, while the unobserved latent variable constructs are shown in ellipses. We show the measurement component using thin lines and the structural component using bold lines. The directions of the arrow represent the hypothesized influence. The four hypotheses are as follows:

H1 Media influence is positively associated with teen influence on FDM

H2 Peer influence is positively associated with teen influence on FDM

$H 3$ Shopping influence is positively associated with teen influence on FDM

$H 4$ Internet influence is positively associated with teen influence on FDM

\section{MODEL RESULTS AND DISCUSSION}

The model assessment in SEM analysis involves two aspects - measurement model and structural model. It is suggested that the measurement model be assessed before the structural model is estimated (Anderson and Gerbing, 1988). The measurement model was assessed through exploratory factor analysis (EFA) and 
then by confirmatory factor analysis (CFA). EFA extracted four factors (representing each socialization agent) using principal components analysis with varimax rotation. All items intended to measure each concept cleanly loaded on their respective hypothesized structures (see appendix 2). To test the reliability of the instrument used in the final study, the coefficient alpha values were computed. At $0.89,0.91,0.90$ and 0.90 for media influence, peer influence, shopping influence and Internet influence respectively, the values well exceed the 0.70 threshold and are therefore acceptable (Nunnally, 1978). In the second step, the measurement model data was subjected to CFA. The AMOS module of the SPSS software package was utilized to estimate the SEM in this study with estimations based on the maximum likelihood method. The results from table 2 indicate that all items have significant loadings on the latent constructs, thus confirming the construct validity (Bagozzi and Yi, 1988). All parameter estimates appear to be reasonable and statistically significant; all standard errors also appear to be in good order. Hence, it can be inferred that latent variable constructs are valid in the specific empirical setting shown in figure 1.

Table 3 provides the parameter estimates for the structural model. The path coefficients are statistically significant for peer, Internet and shopping influence; hence hypotheses $\mathrm{H} 2, \mathrm{H} 3$ and $\mathrm{H} 4$ are strongly supported by the empirical data. The most unexpected finding is the lack of the impact of media influence on teenager's generic influence and that, therefore, H1 does not find support. The reasons can only be speculated. Possibly, teenage children develop skepticism about the commercial intent via media and are more susceptible to personal sources of information, such as peers or their social networks (Internet) or their own first hand experiences via shopping expeditions. Therefore, even if they have sufficient engagement with the media and tend to acquire and disseminate product related knowledge, it may not be disseminated with the same conviction as they do for other sources. Secondly, since the primary leisure activity of Indian adults is also television, co-viewing (or viewing common content) quashes the effect of teenagers' media influence, as parents may also value or may be more convinced by novel information/conviction than the teenagers develop via different mediums (peers, shopping and Internet). To a certain extent, this argument is supported by the fact that Internet influence, though lower than media in measurement, has more potency to influence the teenagers' role in family decision making. 


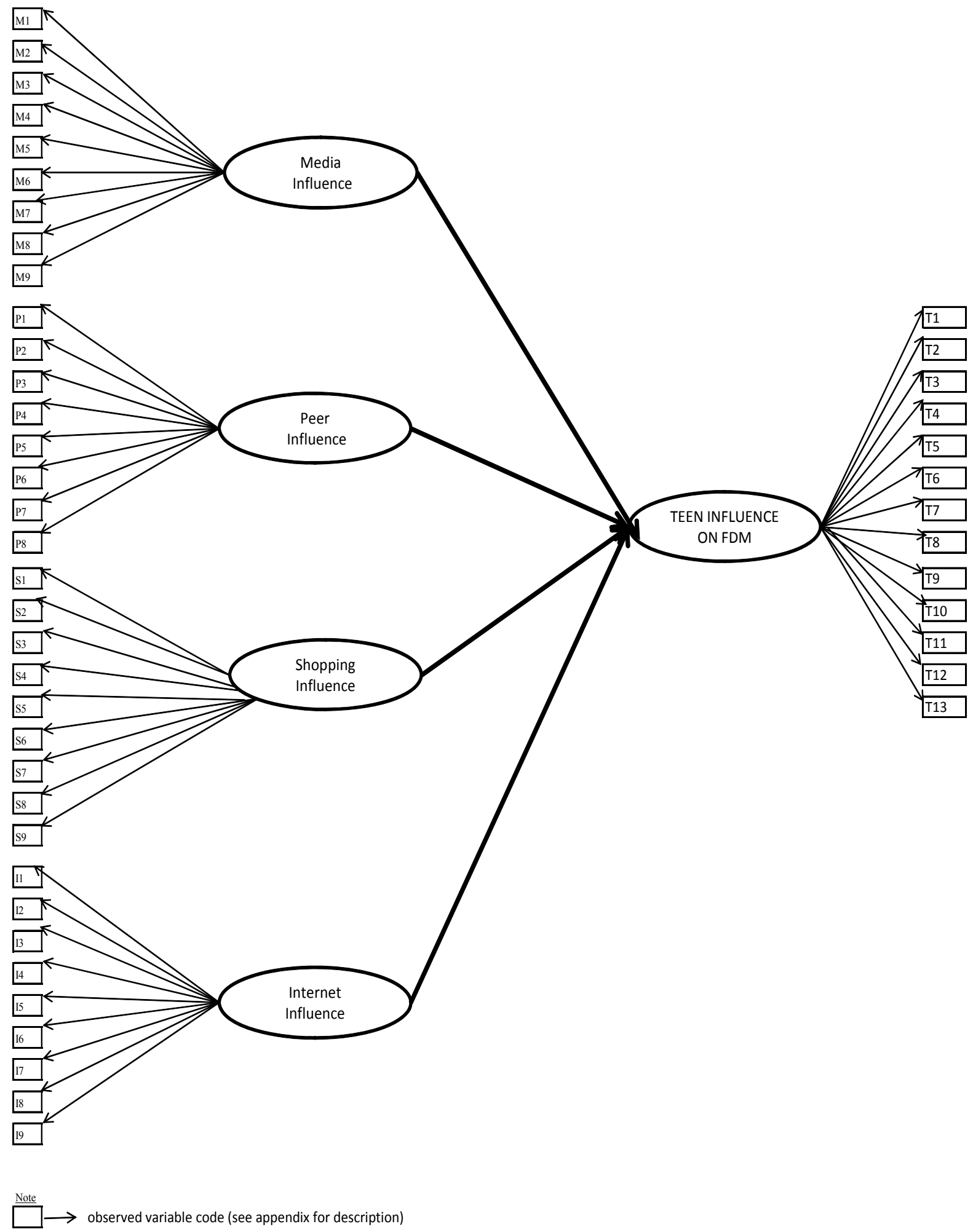

Figure 1 Specification of SEM for Teen Influence in FDM 
In light of the lack of empirical support for media impact on teen influence, the SEM model was re-specified as model 2 (exogenous variable media influence deleted). The re-specification of the model led to better model fit results as can be seen from table 3 . The path coefficients too are positive and statistically significant suggesting that socialization agents like peer, shopping and Internet impact the teen influence in family decision making. The impact of the Internet (coefficient 0.593) is most significant in characterizing teen influence in the family purchases followed by peers and shopping (coefficient 0.548 and 0.446 respectively).

Table1 Correlation Matrix of Major Constructs' Summated Scores

\begin{tabular}{clccccccc}
\hline No. & \multicolumn{1}{c}{ Major Constructs } & Mean & SD & 1 & 2 & 3 & 4 & 5 \\
\hline 1 & Media influence (MI) & 2.33 & 0.66 & 1.00 & & & & \\
2 & Peer Influence (PI) & 3.01 & 0.62 & $.689^{* *}$ & 1.00 & & & \\
3 & Shopping Influence (SI) & 2.81 & 0.69 & $.689^{* *}$ & $.425^{* *}$ & 1.00 & & \\
4 & Internet Influence (II) & 2.11 & 0.62 & $.415^{* *}$ & $.384^{* *}$ & $.276^{* *}$ & 1.00 & \\
5 & Teen Influence on FDM & 2.83 & 0.76 & $.494^{* *}$ & $.651^{* *}$ & $.572^{* *}$ & $.602^{* *}$ & 1.00 \\
\hline Notes: **Correlation is significant at the 0.01 level (two-tailed) & & & & \\
& $*$ Correlation is significant at the 0.05 level (two-tailed) & & & &
\end{tabular}

Table 2 Parameter Estimates of Measurement Model (Relation of Indicator Variables to Latent Variables)

\begin{tabular}{|c|c|c|c|c|c|c|c|c|c|}
\hline \multicolumn{2}{|c|}{$\begin{array}{l}\text { Latent } \\
\text { Variables } \\
\end{array}$} & \multirow{2}{*}{\begin{tabular}{r}
\multicolumn{1}{c}{$\begin{array}{c}\text { Factor } \\
\text { Loadings }\end{array}$} \\
1.911
\end{tabular}} & \multirow{2}{*}{$\begin{array}{r}\text { Standard } \\
\text { error }\end{array}$} & \multirow{2}{*}{$\frac{\text { p-value }}{*}$} & \multirow{2}{*}{$\begin{array}{r}\begin{array}{c}\text { Path } \\
\text { coefficients }\end{array} \\
.840\end{array}$} & \multirow{2}{*}{$\frac{\text { AVE }}{.584}$} & \multirow{2}{*}{$\begin{array}{c}\begin{array}{c}\text { Convergent } \\
\text { validity }\end{array} \\
\text { yes }\end{array}$} & \multirow{2}{*}{$\begin{array}{l}\text { SIC } \\
.213\end{array}$} & \multirow{2}{*}{$\begin{array}{c}\begin{array}{c}\text { Discriminant } \\
\text { validity }\end{array} \\
\text { yes }\end{array}$} \\
\hline MI & M1 & & & & & & & & \\
\hline & M2 & 1.651 & .141 & $*$ & .851 & & & & \\
\hline & M3 & 0.885 & .105 & $*$ & .529 & & & & \\
\hline & M4 & 1.279 & .137 & $*$ & .606 & & & & \\
\hline & M5 & 1.665 & .148 & $*$ & .801 & & & & \\
\hline & M6 & 0.751 & .009 & $*$ & .464 & & & & \\
\hline & M7 & 1.665 & .119 & $*$ & .646 & & & & \\
\hline & M8 & 1.575 & .144 & $*$ & .766 & & & & \\
\hline & M9 & 1.000 & I & I & .585 & & & & \\
\hline \multirow[t]{9}{*}{ PI } & $\mathrm{P} 1$ & 1.290 & .090 & $*$ & .862 & .567 & yes & .268 & yes \\
\hline & $\mathrm{P} 2$ & 0.986 & .083 & $*$ & 691 & & & & \\
\hline & P3 & 1.313 & .094 & $*$ & .832 & & & & \\
\hline & P4 & 1.492 & .101 & $*$ & .891 & & & & \\
\hline & P5 & 1.107 & .086 & $*$ & .771 & & & & \\
\hline & P6 & 0.806 & .086 & $*$ & .541 & & & & \\
\hline & P7 & 1.198 & .096 & $*$ & .728 & & & & \\
\hline & P8 & 1.061 & .096 & $*$ & .642 & & & & \\
\hline & P9 & 1.000 & 1 & 1 & .670 & & & & \\
\hline
\end{tabular}


Table 2 Parameter Estimates of Measurement Model (continued)

(Relation of Indicator Variables to Latent Variables)

\begin{tabular}{|c|c|c|c|c|c|c|c|c|c|}
\hline \multicolumn{2}{|c|}{$\begin{array}{l}\text { Latent } \\
\text { Variables } \\
\end{array}$} & \multirow{2}{*}{\begin{tabular}{r}
\multicolumn{1}{c}{$\begin{array}{c}\text { Factor } \\
\text { Loadings }\end{array}$} \\
0.979
\end{tabular}} & \multirow{2}{*}{$\begin{array}{r}\begin{array}{c}\text { Standard } \\
\text { error }\end{array} \\
.070\end{array}$} & \multirow{2}{*}{$\begin{array}{c}\text { p-value } \\
*\end{array}$} & \multirow{2}{*}{\begin{tabular}{r}
\multicolumn{1}{c}{$\begin{array}{c}\text { Path } \\
\text { coefficients }\end{array}$} \\
.710
\end{tabular}} & \multirow{2}{*}{$\begin{array}{c}\text { AVE C } \\
.605\end{array}$} & \multirow{2}{*}{$\begin{array}{c}\begin{array}{c}\text { Convergent } \\
\text { validity }\end{array} \\
\text { yes }\end{array}$} & \multirow{2}{*}{$\begin{array}{l}\text { SIC } \\
.090\end{array}$} & \multirow{2}{*}{$\begin{array}{c}\begin{array}{c}\text { Discriminant } \\
\text { validity }\end{array} \\
\text { yes }\end{array}$} \\
\hline SI & S1 & & & & & & & & \\
\hline & S2 & 0.985 & .057. & $*$ & .820 & & & & \\
\hline & S3 & 1.045 & .076 & $*$ & .708 & & & & \\
\hline & S4 & 0.862 & .060 & $*$ & .727 & & & & \\
\hline & S5 & 1.008 & .063 & * & .784 & & & & \\
\hline & S6 & 1.064 & .071 & $*$ & .738 & & & & \\
\hline & S7 & 0.897 & .068 & $*$ & .683 & & & & \\
\hline & S8 & 1.000 & / & / & .786 & & & & \\
\hline \multirow[t]{9}{*}{ II } & I1 & 1.000 & I & / & .725 & .589 & yes & .090 & yes \\
\hline & $\mathrm{I} 2$ & 0.902 & 0.069 & $*$ & .721 & & & & \\
\hline & $\mathrm{I} 3$ & 1.066 & 0.081 & $*$ & .725 & & & & \\
\hline & I4 & 0.968 & 0.082 & $*$ & .658 & & & & \\
\hline & I5 & 0.904 & 0.072 & $*$ & .706 & & & & \\
\hline & I6 & 0.703 & 0.066 & $*$ & .590 & & & & \\
\hline & I7 & 1.333 & 0.09 & $*$ & .812 & & & & \\
\hline & I8 & 0.98 & 0.079 & $*$ & .696 & & & & \\
\hline & I9 & 0.987 & 0.076 & * & .724 & & & & \\
\hline \multirow{13}{*}{$\begin{array}{l}\text { Teen } \\
\text { Influ }\end{array}$} & $\mathrm{T} 1$ & 1.007 & 0.057 & * & .764 & \multirow{13}{*}{\multicolumn{2}{|c|}{.784 yes }} & .172 & yes \\
\hline & $\mathrm{T} 2$ & 0.757 & 0.051 & $*$ & .676 & & & & \\
\hline & $\mathrm{T} 3$ & 0.956 & 0.061 & $*$ & .707 & & & & \\
\hline & $\mathrm{T} 4$ & 1.091 & 0.056 & $*$ & .804 & & & & \\
\hline & T5 & 0.666 & 0.064 & * & .523 & & & & \\
\hline & T6 & 0.746 & 0.057 & $*$ & .626 & & & & \\
\hline & $\mathrm{T} 7$ & 0.913 & 0.049 & $*$ & .783 & & & & \\
\hline & $\mathrm{T} 8$ & 0.653 & 0.043 & $*$ & .691 & & & & \\
\hline & T9 & 0.763 & 0.063 & $*$ & .587 & & & & \\
\hline & $\mathrm{T} 10$ & 0.943 & 0.071 & $*$ & .638 & & & & \\
\hline & $\mathrm{T} 11$ & 0.726 & 0.063 & $*$ & .568 & & & & \\
\hline & T12 & 0.725 & 0.061 & $*$ & .578 & & & & \\
\hline & $\mathrm{T} 13$ & 1.000 & 1 & 1 & .878 & & & & \\
\hline
\end{tabular}

Notes: $(/)=$ Indicatesthe initial parameter was set to 1.0 for model estimation purposes;

Abbreviations: $\mathrm{AVE}=$ average variance extracted $(\mathrm{AVE}>0.50=$ Convergent validity).

$\mathrm{SIC}=$ squared interconsctruct correlation estimates. Discriminant validity $=\mathrm{AVE}>\mathrm{SIC}$ 
Table 3 Path Coefficients and Fit Indices

\begin{tabular}{|c|c|c|c|c|c|}
\hline \multirow[t]{2}{*}{ Path } & \multirow[t]{2}{*}{ Hypothesis } & \multicolumn{2}{|c|}{ Model 1} & \multicolumn{2}{|c|}{ Model 2} \\
\hline & & $\begin{array}{l}\text { Standardized } \\
\text { coefficients }\end{array}$ & t-value & $\begin{array}{l}\text { Standardized } \\
\text { coefficients }\end{array}$ & t-value \\
\hline $\begin{array}{l}\text { Media influence } \rightarrow \text { Teen } \\
\text { Influence }\end{array}$ & $\mathrm{H} 1$ & -.052 & -.840 & & \\
\hline $\begin{array}{l}\text { Peer influence } \rightarrow \text { Teen } \\
\text { Influence }\end{array}$ & $\mathrm{H} 2$ & .321 & $.076^{* *}$ & .548 & $7.446 * *$ \\
\hline $\begin{array}{l}\text { Shopping Influence } \rightarrow \\
\text { Teen Influence }\end{array}$ & $\mathrm{H} 3$ & .403 & $.088^{* *}$ & .446 & $7.983 * *$ \\
\hline $\begin{array}{l}\text { Internet influence } \rightarrow \text { Teen } \\
\text { Influence }\end{array}$ & $\mathrm{H} 4$ & .438 & $9.268 * *$ & .593 & $9.480 * *$ \\
\hline \multicolumn{6}{|l|}{ Model Fit indices } \\
\hline 1) $X^{2}$ & & 5077.278 & & 2134.734 & \\
\hline $\begin{array}{l}\text { 2) Degree of freedom } \\
\text { (df) }\end{array}$ & & 1117 & & 734 & \\
\hline 3) $P$-value & & .000 & & .000 & \\
\hline \multicolumn{6}{|c|}{ Good fit } \\
\hline 4) $X^{2} / \mathrm{df}$ & $0 \leq\left(X^{2} / \mathrm{df}\right) \leq 2$ & 4.54 & & 2.90 & \\
\hline 5) NFI & $\geq .95$ & .82 & & .942 & \\
\hline 6) $\mathrm{CFI}$ & $\geq .95$ & .86 & & .967 & \\
\hline 7) GFI & $\geq .95$ & .79 & & .971 & \\
\hline 8) AGFI & $\geq .95$ & .84 & & .949 & \\
\hline 9) RMSEA & $<.06$ & .08 & & .04 & \\
\hline
\end{tabular}

\section{CONCLUSIONS}

This study focuses on a "teen influence" construct in family decision making and its predictors. The traditional socialization agents, such as media, peers and such contemporary agents as shopping and the Internet, were hypothesized as predictors of teen influence in family decision making. The findings from the empirical data suggest that peer, shopping and the Internet are significant predictors of teen influence in family purchases. It can be concluded that a teenager's engagement with these mediums and the consumption of information acquired and disseminated from these mediums lead to a greater degree of influence in family decision making.

In terms of the methodology used, the study breaks fresh ground. The use of the SEM approach provided for the construct validity of the key constructs namely, media influence, peers influence, shopping influence and Internet influence. All four scales are developed on common dimensions, so that they may be employed in isolation or in 
a comparative manner to wield results of significance by future researchers. In addition to these measures, the construct validity of the generic measure of teen influence (not specific to any product or product category) of children in family decisions is established. To a certain extent, this answers the call from the extant literature vis a vis the construct validity of the measures in the research pertaining to child influence in the FDM.

The findings of the study are contemporary in nature and facilitate better insights. For instance, the study found that, although media influence is larger than the Internet in quantum (mean value 2.33 versus 2.11 respectively), its role is marginalized as a predictor when compared to the influence that teenagers have in family decision making. Obviously, this requires more investigation. Academic research needs to be initiated to uncover the effects of co-viewing, skepticism to commercial intent and other reasons for the possible marginalization of the role of media amidst contemporary influences like the Internet. Thereafter, acknowledging the influence of commercial set ups (shopping) and the Internet on children, marketing strategies can integrate these media to reach out to this influential segment, which globally boasts more than $\$ 592$ billion in personal purchase power. For example, in commercial set ups, store design and layout, training of frontline staff, product display, and recreation facilities, etc. may require considerable attention. Also, in recognition of the fact that teenagers have a greater online presence than adults and may be actively disseminating Internet acquired consumer knowledge within the household, web marketing communications may now require a realignment to suit the comprehension and the maturity level of this group. The Internet can prove to be a great channel for marketers to create a buzz through newsgroups, chat rooms and blogs about products ranging from clothes to music.

In addition, traditional media of consumer socialization, such as peers and media, still hold significance, although the role of media has to be revisited. Though the teenagers have sufficient engagement with media and tend to acquire and disseminate consumer information in the household, these factors do not necessarily culminate in a larger role in family decision making. Therefore, media communication needs more ingenuity and novelty in design. On the other hand, peers still exert considerable influence on the consumer behavior of the teenagers. In view of the fact that teenagers not only highly value peer relationships but tend to acquire and disseminate much product information from their peers, so much so that it acts as a significant predictor of their own influence in the households; marketers may manipulate peer group influences in their promotional appeals and in encouraging product selection. 
Fundamentally, for the marketers, the results demonstrate that teenage children can no longer be treated as passive beneficiaries of family purchase decisions. Rather, their role needs to be acknowledged and understood to formulate marketing offerings productively for target markets. This is in line with what was so far notionally known - that "pester power" has just become savvier, smarter, and more informed. Rather than nagging their parents to unleash their rising disposable incomes at random and flashy products and services that catch their eye, more and more of India's close to 400 million children below the age of 15 are becoming connoisseurs and specialists that their parents rely on (Sethi, 2011).

This study is meaningful but does have some limitations. The specified SEM model is not completely exhaustive. Such factors of relevance as socio-economic characteristics of teenager and parents were not included in the model. Additionally, the study sample was restricted to one geographical location, Delhi (and adjoining areas). Although Delhi is widely acknowledged as having a rich cultural milieu with a strong presence of immigrant population, future studies may include a broader geographical landscape to increase the generalizability of the patterns obtained here. Also, the study concentrated only on urban families, as it was necessary to limit the study somewhat. Rural consumption behavior may be altogether different. In spite of the limitations, given the limited research attention on children's influence on decision making, especially outside of the US and other Western nations, it is expected that this study will provide meaningful insight on the role of teenagers in family purchase decisions.

\section{REFERENCES}

Anderson, J. C. \& Gerbing, D. W. (1988). Structural equation modeling in practice: a review and recommended two-step approach. Psychological Bulletin, 103(3), 41123. http://dx.doi.org/10.1037\%2F\%2F0033-2909.103.3.411

Bagozzi, R. \& Yi, Y. (1988). On the evaluation of structural equation models. Journal of the Academy of Marketing Science, 16 (Spring), 74-94. http://dx.doi.org/10.1007\%2FBF02723327

Belch, G., Belch, M. A. \& Ceresino, G. (1985). Parental and teenage influences in family decision making. Journal of Business Research, 13 (April),163-176. http://dx.doi.org/10.1016\%2F0148-2963\%2885\%2990038-4

Bush, D. M. \& Simmons, R. G. (1981). Socialization Processes Over the Life Course. In M.Rosenberg and R. H. Turner (eds.) Social Psychology: Sociological Perspectives. (pp. 133-164). New York: Basic Books. 
Chavda, H., Haley, M. \& Dunn, C. (2005). Adolescents' influence on family decision making, $\quad$ Young Consumers, 6 (3),68-78. http://dx.doi.org/10.1108\%2F17473610510701223

Childers, T. L. \& Rao, A. R. (1992). The influence of familial and peer based children. Journal of Consumer Research, 12 (March), 962-967.

Hundal, B. S. (2001). Consumer Behaviour in Rural Market: A Study of Durables. Unpublished Doctoral Dissertation, Guru Nanak Dev University, Amritsar.

Ekstrom, K. M. (1995). Children's influence in family decision making. (Unpublished doctoral dissertation). University of Gothenburg, Sweden.

Kapoor, S. (2001). Family Influence on Purchase Decisions- A Study with Reference to Consumer Durables. Unpublished Doctoral Dissertation, University of Delhi, Delhi.

Kaur, A. \& Medury, Y. (2010). Traditional and contemporary influences on consumer socialization: results from an exploratory in India.

Kaur, A. \& Medury, Y. (2011a). Impact of familial characteristics on Indian children's influence in family purchases. International Journal of Indian Culture and Business Management, 4(1), $104-122$.

Kaur, A. \& Medury, Y. (2011b). Impact of the internet on teenagers' influence on family purchases. Young Consumers: Insight and Ideas for Responsible Marketers, 12(1), 27 - 38. http://dx.doi.org/10.1108\%2F17473611111114768

Kearney, A. T. (2010). Global retailers: expansion opportunities in 2010. Retrieved from http://www.atkearney.com/images/global/pdf/GRN_July_2010.pdf

Kim, C., Lee, H. \& Sharma, A. (1990). Adolescent's power and perceived influence in family purchase decisions. Developments in Marketing Science, Proceedings of the thirteenth annual conference of the Academy of marketing science, New Orleans, Lousinia, 25-29.

Lee, C. K., Conroy, D. M. \& Hii, C. (2003). The internet: a consumer socialization agent for teenagers. ANZMAC 2003 Conference Proceedings, Adelaide, 1-3 December. 1708-1715.

Loudan, D.L. \& Bitta, A. J. L. (1988). Consumer Behavior. Concepts and Applications, USA: McGraw-Hill Inc.

Martin, C. A \& Bush, A. J. (2000). Do role models influence teenagers' purchase indentations and behavior? Journal of Consumer Marketing, 17(5), 441-454. http://dx.doi.org/10.1108\%2F07363760010341081 
Montgomery, K. (2000). Youth and digital media: A policy research agenda. Journal of Adolescent Health, 27(2), 61-68. http://dx.doi.org/10.1016\%2FS1054139X\%2800\%2900130-0

NRIFinanceGuide.com (2008). Why should investors start investing in Indian financial markets? Retrieved from http:// nrifinanceguide.com/ 2008/08/08/whyshould-investors-startinvesting-in-indian-financial-markets-cover-story/

Nunnally, J. C. (1978). Psychometric Theory (2nd ed.). New York, NY: McGraw-Hill.

Roedder-John, D. (1999).Consumer socialization of children: a retrospective look at 25 years of research. Journal of Consumer Research, 26 (December), 183-213.

Ruth, J., \& Commuri, S.R. (1998). Shifting roles in family decision making. Advances in Consumer Research, 25, Provo, UT: Association for Consumer Research, 400406.

Schreiber, J.B., Stage, F.K., Nora, A., \& Barlow, E.A. (2006). Reporting Structural Equation modeling and Confirmatory factor analysis results: A Review. Journal of Educational Research, $99 \quad$ (6), $323 \quad-\quad 338$. http://dx.doi.org/10.3200\%2FJOER.99.6.

Sethi, A. (2011). The kid in the driver seat. Rerieved from http://timesofindia.indiatimes.com/home/sunday-toi/special-report/ChildrensDay-The-kid-in-the-drivers-seat/articleshow/10710955.cms.

Singh, R., \& Kaur (2004). Role-Structures in the Buying Decision Process for Durables, Paradigm, January-June.

Stock, T., \& Tupot, M.L. (2006). Common denominators: what unites global youth? Young Consumers: Insight and Ideas for Responsible Marketers, 7(2), 36 - 43. http://dx.doi.org/10.1108\%2F17473610610701475

Technopak Advisors (2010). India Retail Report. Retrieved from www.retailinasia.com/article/markets/india/2010/12/indias-retail-industry-touchusd $82 b-2020$

Ullman, J. B. (2001). Structural equation modeling. B. G. Tabachnick \& L. S. Fidell (Eds.), Using multivariate statistics (4th ed.). Needham Heights, MA: Allyn \& Bacon.

Webster, C. (1994). Effects of Hispanic ethic identification on marital roles in the purchase decision process. Journal of Consumer Research, 21 (September) 31931.

Wechsler, P. (1997). Hey, kid, buy this!, Business Week, June 30, 62-67.

Wilkie, W. L. (1986). Consumer Behavior, John Wiley and Sons. 
Wimalsari, J. S. (2004). A cross-national study on children's purchasing behavior and parental response. Journal of Consumer Marketing, 21, 274-284. http://dx.doi.org/10.1108\%2F07363760410542183

\section{APPENDIX}

Appendix 1 Questionnaire for Parent for The Measure Perceived Influence with Mean, Standard Deviations and Factor Loadings

As parents,

We seek information ( from the child) for products of child's use

Mean S.D Factor 1

T2 We seek information ( from the child) for products of household use

T3 We seek information ( from the child) for products of our use We like to take our child along while shopping for products of child's use We like to take our child along while shopping for products of household use We like to take our child along while shopping for products of our use

In case of conflict in choice of product or brand, we consider the child's request if the product is of child's use

In case of conflict in choice of product or brand, we consider the child's request if the product is of household use In case of conflict in choice of product or brand, we consider the child's request if the product is of our use

T10 My child is participative in suggesting where we should shop from

T11 My child is participative in suggesting when we should go out shopping

T12 My child is participative in suggesting how much we should spend The involvement of my child in purchase decisions increasesat the time of festivals and other family occasions

Perceived Influence of parent on child influence on FDM

Eigen Value

Percentage of Variance explained

$\begin{array}{lll}3.02 & 1.13 & 0.84\end{array}$

$\begin{array}{lll}2.75 & 0.96 & 0.69\end{array}$

$2.51 \quad 1.16 \quad 0.68$

$3.24 \quad 1.16 \quad 0.76$

$\begin{array}{lll}3.01 & 1.09 & 0.38\end{array}$

$\begin{array}{lll}2.54 & 1.02 & 0.70\end{array}$

$3.01 \quad 1.00 \quad 0.86$

$\begin{array}{lll}2.65 & 0.81 & 0.67\end{array}$

$\begin{array}{lll}2.42 & 1.11 & 0.47\end{array}$

$\begin{array}{lll}2.98 & 1.27 & 0.51\end{array}$

$\begin{array}{lll}3.02 & 1.10 & 0.73\end{array}$

$\begin{array}{lll}2.61 & 1.07 & 0.71\end{array}$

$\begin{array}{lll}3.10 & 0.98 & 0.80\end{array}$

$2.83 \quad 0.76$ 
Appendix 2 Questionnaire for Teenager for The Measures: Media influence, Peer Influence, Shopping Influence and Internet Influence

\begin{tabular}{|c|c|c|c|c|c|c|c|}
\hline & & Mean & S.D. & Factor1 & Factor2 & Factor3 & Factor4 \\
\hline \multicolumn{8}{|c|}{ Media Influence } \\
\hline M1 & I like to watch TV every day & 2.31 & 1.05 & & & 0.74 & \\
\hline M2 & $\begin{array}{l}\text { On holidys I watch more TV than } \\
\text { usual }\end{array}$ & 2.64 & 0.89 & & & 0.80 & \\
\hline M3 & $\begin{array}{l}\text { There are some programs which I do } \\
\text { not like to miss }\end{array}$ & 2.56 & 0.77 & & & 0.38 & \\
\hline M4 & Watching the commercials is fun & 2.13 & 0.97 & & & 0.35 & \\
\hline M5 & $\begin{array}{l}\text { I come to know about products* from } \\
\text { TV which are of my use }\end{array}$ & 2.44 & 0.96 & & & 0.80 & \\
\hline M6 & $\begin{array}{l}\text { I come to know* about products from } \\
\text { TV which are of family use }\end{array}$ & 2.64 & 0.75 & & & 0.37 & \\
\hline M7 & $\begin{array}{l}\text { I come to know* about products from } \\
\text { TV which are of my parent's use }\end{array}$ & 1.77 & 0.83 & & & 0.38 & \\
\hline M8 & $\begin{array}{l}\text { I often discuss about products that I } \\
\text { have seen on TV with my family }\end{array}$ & 2.16 & 0.95 & & & 0.76 & \\
\hline M9 & $\begin{array}{l}\text { I insist my parets to co view some } \\
\text { commercials when we are about to } \\
\text { purchase the product }\end{array}$ & 2.57 & 0.78 & & & 0.83 & \\
\hline & Cronbach alpha & & & & & 0.89 & \\
\hline & Eigen value & & & & & 3.54 & \\
\hline & Percentage of variance explained & & & & & 9.85 & \\
\hline \multicolumn{8}{|c|}{ Peer Influence } \\
\hline $\mathrm{P} 1$ & I like to spend with my friends & 3.39 & 0.78 & 0.84 & & & \\
\hline $\mathrm{P} 2$ & $\begin{array}{l}\text { I have friends with whom I meet or } \\
\text { talk on a daily basis }\end{array}$ & 3.28 & 0.74 & 0.76 & & & \\
\hline P3 & My friends opinions matter to me & 3.18 & 0.83 & 0.83 & & & \\
\hline P4 & $\begin{array}{l}\text { There are certain issues which I dicuss } \\
\text { only with my friends }\end{array}$ & 3.31 & 0.88 & 0.86 & & & \\
\hline P5 & $\begin{array}{l}\text { I come to know* about products from } \\
\text { my friends which are of my use }\end{array}$ & 3.16 & 0.76 & 0.73 & & & \\
\hline P6 & $\begin{array}{l}\text { I come to know* about products from } \\
\text { my friends which are of family use }\end{array}$ & 2.62 & 0.79 & 0.46 & & & \\
\hline P7 & $\begin{array}{l}\text { I come to know* about products from } \\
\text { my friends which are of my parent's } \\
\text { use }\end{array}$ & 2.47 & 0.86 & 0.78 & & & \\
\hline P8 & $\begin{array}{l}\text { I discuss the information about } \\
\text { products my friends have told me with } \\
\text { my parents }\end{array}$ & 2.75 & 0.87 & 0.68 & & & \\
\hline P9 & $\begin{array}{l}\text { Sometimes my parents ask to find } \\
\text { information about some products from } \\
\text { my friends }\end{array}$ & 2.76 & 0.78 & 0.72 & & & \\
\hline & Cronbach alpha & & & 0.91 & & & \\
\hline & Eigen value & & & 11.54 & & & \\
\hline & Percentage of variance explained & & & 32.05 & & & \\
\hline
\end{tabular}


Appendix 2 Questionnaire for Teenager for The Measures: Media influence, Peer Influence, Shopping Influence and Internet Influence (continued)

\begin{tabular}{|c|c|c|c|c|c|c|c|}
\hline \multirow{2}{*}{\multicolumn{8}{|c|}{ Factor1 Factor2 Factor3 Factor4 }} \\
\hline & & & & & & & \\
\hline S1 & I like to go out shopping & 2.83 & 0.93 & & & & 0.45 \\
\hline $\mathrm{S} 2$ & $\begin{array}{l}\text { I go to shop at least twice or thrice a } \\
\text { month }\end{array}$ & 2.89 & 0.80 & & & & 0.78 \\
\hline S3 & $\begin{array}{l}\text { I have some preferences about where } \\
\text { to go to shop }\end{array}$ & 2.88 & 1.00 & & & & 0.54 \\
\hline S4 & $\begin{array}{l}\text { I can interact with the salesperson to } \\
\text { know more about products }\end{array}$ & 2.81 & 0.81 & & & & 0.39 \\
\hline S5 & $\begin{array}{l}\text { I come to know* about products of my } \\
\text { use from my shopping experiences }\end{array}$ & 2.81 & 0.87 & & & & 0.56 \\
\hline S6 & $\begin{array}{l}\text { I come to know* about products of } \\
\text { family use from my shopping } \\
\text { experiences }\end{array}$ & 2.73 & 0.96 & & & & 0.84 \\
\hline S7 & $\begin{array}{l}\text { I come to know* about products of my } \\
\text { parent's use from my shopping } \\
\text { experiences }\end{array}$ & 2.81 & 0.89 & & & & 0.38 \\
\hline S8 & $\begin{array}{l}\text { I share with my parents the } \\
\text { information about products I have seen } \\
\text { while shopping alone or with friends }\end{array}$ & 2.75 & 0.85 & & & & 0.82 \\
\hline & Cronbach alpha & & & & & & 0.90 \\
\hline & Eigen value & & & & & & 1.85 \\
\hline & Percentage of variance explained & & & & & & 5.15 \\
\hline \multicolumn{8}{|c|}{ Internet Influence } \\
\hline I1 & I acess internet everyday & 2.12 & 0.86 & & 0.72 & & \\
\hline $\mathrm{I} 2$ & $\begin{array}{l}\text { On holidays, I spend more time than } \\
\text { usual surfing net }\end{array}$ & 2.01 & 0.77 & & 0.75 & & \\
\hline $\mathrm{I} 3$ & $\begin{array}{l}\text { I find using internet more enjoyable } \\
\text { than watching TV }\end{array}$ & 2.12 & 0.90 & & 0.76 & & \\
\hline $\mathrm{I} 4$ & $\begin{array}{l}\text { I come to know *about products for } \\
\text { my use from internet }\end{array}$ & 2.18 & 0.92 & & 0.68 & & \\
\hline I5 & $\begin{array}{l}\text { I come to know*about products for } \\
\text { family use from internet }\end{array}$ & 2.06 & 0.81 & & 0.67 & & \\
\hline I6 & $\begin{array}{l}\text { I come to know* about products for } \\
\text { my parents use from internet }\end{array}$ & 1.95 & 0.73 & & 0.66 & & \\
\hline I7 & $\begin{array}{l}\text { I discuss the information about } \\
\text { products I have viewed on internet } \\
\text { with my parents }\end{array}$ & 2.21 & 1.01 & & 0.82 & & \\
\hline I8 & $\begin{array}{l}\text { Sometimes I insist my parets to co } \\
\text { view the information about the } \\
\text { products we are about to purchase }\end{array}$ & 2.13 & 0.89 & & 0.69 & & \\
\hline I9 & $\begin{array}{l}\text { Sometimes my parents ask me to find } \\
\text { information about products on the } \\
\text { internet }\end{array}$ & 2.12 & 0.86 & & 0.74 & & \\
\hline \multicolumn{4}{|c|}{ Cronbach alpha } & & 0.90 & & \\
\hline \multicolumn{4}{|c|}{ Eigen value } & & 4.36 & & \\
\hline \multicolumn{4}{|c|}{ Percentage of variance explained } & & 12.12 & & \\
\hline \multicolumn{8}{|c|}{$\begin{array}{l}\text { Extraction method : Principal Component Analysis } \\
\text { Rotation method : Varimax with Kaiser Normalization } \\
\text { Factor loadings less than } .38 \text { not shown } \\
\text { * (brands, features, prices and availibility etc.) }\end{array}$} \\
\hline
\end{tabular}

